\title{
Pendampingan Pengukuran Arah Kiblat Masjid di Rancabango Garut
}

\author{
Fahmi Fatwa RSH, Ramdan Fawzi, Rifki Gapuraning Syahid \\ Universitas Islam Bandung \\ Email : fatwa19@gmail.com
}

\begin{abstract}
Facing Ka'bah is one of the requirements for the validity of prayer. Problem in straightening saf in mosques had become a heavy topic, Some Council of Mosque Prosperity (DKM) assumes that straightening direction qibla means rebuilding the mosque, whereas what should be changed is only the direction of the saf prayer). Some mosques in the village of Rancabango SubDistrik Tarogong Kaler and village of Wangunsari Kampung Areng Lembang, the direction of qibla should be re-verified by the institutions that have the force of law. Therefore, this research aims to know the opinions of the muftis in determining the qibla direction and the factors that influence the inaccuracy of the qibla direction. The methods used in this research is descriptive-analysis, that is describing systematically and factually about facts, conditions, and situation of the mosque building. It can be concluded that the muftis agree about the condition of facing the qibla for people who looks the Ka'bah, then the prayer faces/overlooks 'ainul Ka'bah, whereas for people who cannot see the Ka'bah, then the prayer faces towards jihatul Ka'bah. As for the direction of mosques showed that some mosques still have an accuracy that is less accurate to the price of the specified angle.
\end{abstract}

Abstrak: Menghadap Ka 'bah adalah salah satu persyaratan untuk validitas doa. Masalah dalam meluruskan saf di masjid telah menjadi topik yang berat, Beberapa Dewan Kemakmuran Masjid (DKM) menganggap bahwa meluruskan arah kiblat berarti membangun kembali masjid, padahal apa yang perlu diubah hanyalah arah saf sholatnya saja. Beberapa masjid di desa Rancabango Kecamatan Tarogong Kaler dan juga desa Wangunsari Kampung Areng Lembang, arah kiblat perlu diverifikasi ulang oleh institusi yang memiliki kekuatan hukum. Oleh karena itu, penelitian ini bertujuan untuk mengetahui pendapat para mufti dalam menentukan arah kiblat dan faktor-faktor yang mempengaruhi melencengnya arah kiblat. Metode yang digunakan dalam penelitian ini adalah deskriptif-analisis, yaitu menggambarkan secara sistematis dan faktual tentang fakta, kondisi, dan situasi bangunan masjid. Dapat disimpulkan bahwa para mufti setuju tentang kondisi menghadapi kiblat bagi orang-orang yang melihat Ka'bah, maka doa menghadap / menghadap 'ainul Ka'bah, sedangkan bagi orang-orang yang tidak dapat melihat Ka'bah, maka doa menghadap ke arah jihatul Ka'bah. Adapun arah masjid menunjukkan bahwa 
beberapa masjid masih memiliki akurasi yang kurang akurat dengan harga sudut yang ditentukan.

Kata Kunci: Arah Kiblat, Masjid, Saf Salat.

\section{PENDAHULUAN}

Arah kiblat mungkin bukan menjadi persoalan yang dianggap penting bagi sebagian besar masyarakat di Indonesia sebagaimana pentingnya penentuan awal bulan kamariah dan waktu salat (hamdani, Alhamuddin, Mochammad, 2016). Namun, menjadi penting apabila seorang muslim akan melaksanakan ibadah salat, menguburkan jenazah, atau bahkan saat membangun wc, dan lain sebagainya. Hal ini dikarenakan maksud anjuran dan perintah yang tersirat dalam al-Qur'an maupun hadis perlu diperhatikan dan dilaksanakan.

Menghadap kiblat merupakan salah satu syarat sah salat. Allah Swt memberikan penekanan terhadap ketentuan arah kiblat umat muslim menghadap ke arah Masjidil Haram (Ka'bah), dalam firman-Nya QS. al-Baqarah (2): 149-150. Ayat-ayat ini menjadi dasar hukum bagi seorang muslim untuk menghadapkan diri ke arah Ka'bah ketika salat. Allah SW'T banyak menyinggung dan menekankan persoalan tentang arah kiblat dalam QS. al-Baqarah ayat 142150. Majelis Ulama Indonesia melalui fatwa no. 5 tahun 2010 memberikan penjelasan tentang arah kiblat umat muslim di Indonesia yaitu ke arah Barat agak ke Utara. Oleh karenanya, bagi umat muslim yang berada di Indonesia, tentunya membutuhkan usaha yang maksimal dalam menentukan arah kiblat.

Selama ini, persoalan tentang arah kiblat masjid maupun musala di beberapa daerah seolah belum pernah "tersentuh" oleh pemerintah. Hal ini dapat diketahui dari banyaknya bangunan masjid yang arah kiblatnya perlu diverifikasi ulang. Termasuk arah kiblat masjid-masjid yang ada di Desa Rancabango Kecamatan Tarogong Kaler Kabupaten Garut dan juga masjidmasjid yang berada di Desa Wangunsari Kecamatan Lembang Kabupaten Bandung Barat. Pasalnya, masjid-masjid tersebut sering digunakan oleh masyarakat sekitar untuk salat berjama'ah lima waktu.

Adanya isu-isu tentang penyimpangan arah kiblat dikarenakan terjadinya pergeseran lempengan bumi atau bencana alam lainnya seperti gempa bumi dan tanah longsor, tidak jarang dijadikan sebagai alasan yang menyebabkan melencengnya arah kiblat masjid-masjid tersebut. Upaya untuk meluruskan arah kiblat bukan persoalan yang mudah untuk dilakukan, apalagi dengan kondisi sumber daya manusia (SDM) yang ada saat ini. Dalam praktiknya, diperlukan kondisi, motivasi, fasilitas, metode, dan strategi belajar yang tepat agar 
pembelajaran dan sosialisasi tentang arah kiblat untuk para Dewan Kemakmuran Masjid (DKM) dan tokoh masyarakat setempat dapat berlangsung dengan optimal.

Pemberdayaan SDM menjadi subjek dampingan dalam kegiatan penelitian ini akan sangat membantu peneliti untuk lebih mudah memverifikasi arah kiblat masjid. Ditambah lagi dengan semakin canggihnya teknologi saat ini yang dapat memberikan kemudahan dalam meluruskan saf salat.

Beberapa penelitian tentang verifikasi arah kiblat masjid yang dilakukan Syarif (2012), Mulyadi (2013), Jayusman (2014), Kamal (2015), Awaluddin dkk. (2016), Darajat dkk. (2016), dan para peneliti lainnya, banyak dijumpai sebagian besar arah kiblat bangunan-bangunan masjid yang diverifikasi, arah kiblatnya tidak akurat. Oleh karenanya diperlukan pengecekan ulang, baik dengan menggunakan google earth, mizwala, theodolite, kompas magnet, ataupun instrumen arah kiblat lainnya.

Meskipun hanya sebagian masyarakat yang sadar dan beberapa saja yang mengetahui bagaimana cara memanfaatkan teknologi tersebut, peneliti terdorong untuk melakukan kegiatan penelitian dan pengabdian kepada masyarakat dengan melakukan sosialisasi, penyuluhan, maupun pelatihan tentang arah kiblat yang ditujukan kepada para pengurus masjid dan juga masyarakat umum. Adapun pada tahapan awal, peneliti melakukan pengecekan bersama tim untuk mendapatkan hasil verifikasi arah kiblat setiap bangunan-bangunan masjid yang dijadikan objek penelitian.

\section{KAJIAN MENGHADAP KIBLAT}

Ka'bah adalah sebuah bangunan suci berbentuk kubus yang merupakan pusat berbagai peribadatan umat muslim. Oleh sebab itu Ka'bah disebut sebagai kiblat karena ia menjadi arah yang dituju oleh setiap muslim dalam beribadah. Umat muslim menghadap Ka'bah dalam salat bukan untuk menyembah Ka'bah, akan tetapi pada hakikatnya umat muslim hanya menyembah dan bersujud kepada Allah (Naik, 2016: 11).

Ka'bah dibangun pertama kali pada 2000 (dua ribu) tahun sebelum penciptaan dunia (Mulyadi, 2013: 78). Nabi Adam as dianggap sebagai peletak dasar bangunan Ka'bah di bumi. Setelah Nabi Adam as wafat, bangunan Ka'bah diangkat ke langit. Kemudian lokasi tersebut dari masa ke masa diagungkan dan disucikan oleh umat para nabi. Pada masa Nabi Ibrahim as dan putranya Nabi Ismail as, lokasi tersebut digunakan untuk membangun kembali sebuah rumah ibadah. Setelah mereka wafat, pemeliharaan Ka'bah dilanjutkan oleh keturunannya, setelah itu oleh Bani Jurhum, lalu Bani Khuza'ah yang 
memperkenalkan penyembahan berhala di sekitar Ka'bah. Pemeliharaan Ka'bah setelah masa itu dilanjutkan oleh Kaum Quraisy. Ka'bah dipelihara oleh Abdul Muthalib, kakek Nabi Muhammad saw. (Mulyadi, 2013: 78).

Pada awal sebelum berhijrah ke Madinah, Nabi Muhammad saw dan kaum muslimin dalam mendirikan salat menghadap ke Ka’bah di Makkah. Namun ketika beliau bersama para sahabat hijrah ke Madinah, Rasulullah saw dan kaum muslim dalam salat mengarah ke Baitul Maqdis, Masjidil Aqsa, Jerusalem di Palestina. Beliau salat menghadap ke Baitul Maqdis selama 16 atau 17 bulan (Mulyadi, 2013: 78). Setelah sekian lama kaum muslim mengarahkan kiblat ke Baitul Maqdis, namun orang-orang Yahudi tetap tidak menerima ajaran Islam.

Setelah melihat kenyataan tersebut Nabi Muhammad saw yakin, bahwa memilih Baitul Maqdis sebagai kiblat tidak mencapai tujuannya, bahkan kurang tepat jika dibanding dengan mengarahkan kiblat ke Ka'bah. Baitullah Ka'bah adalah rumah peribadatan pertama yang dibangun manusia, yakni jauh sebelum Baitul Maqdis dibangun. Di sisi lain, Ka'bah adalah arah leluhur Nabi Muhammad saw. Oleh sebab itu, terbetiklah dalam hati beliau keinginan untuk kembali mengarahkan kiblat ke Ka'bah di Makkah, sebagaimana sebelum beliau berhijrah ke Madinah (Mulyadi, 2013: 78).

Pemindahan kiblat dari Baitul Maqdis ke Ka'bah di Makkah membuat beliau SAW merasa senang untuk dipalingkan kembali ke arah Ka'bah, meskipun orang-orang Yahudi banyak yang beranggapan bahwa Muhammad SAW tidak konsisten dengan pilihannya di mana pada Muhammad SAW pernah menyelisihi mereka (kaum Yahudi), namun pada akhirnya kembali mengikuti kiblat mereka (Aswalani, 2003: 73). Peristiwa tersebut kemudian sampai saat ini dijadikan suatu ketetapan bagi umat muslim untuk menghadap ke Ka'bah ketika beribadah. Berkaitan dengan hal tersebut di atas, ada sebuah riwayat yang menjelaskan tentang perpindahan kiblat kembali ke Ka'bah,

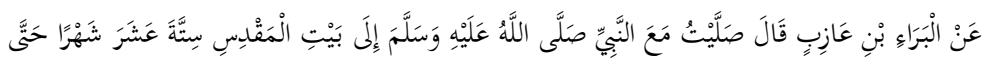

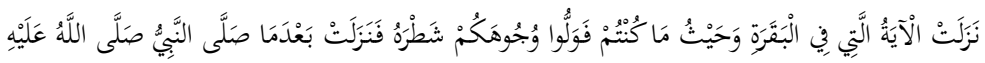

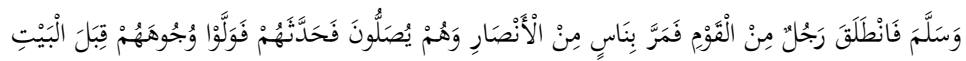

'Dari Al Barra' bin 'Azib RA, dia berkata, "Saya salat bersama Nabi $S A W$ menghadap ke Baitul Maqdis selama 16 bulan sehingga turunlah ayat di dalam surah Al Baqarah, "Dan dimana saja kamu berada maka palingkanlah mukamu ke arah masjidil haram" \{Qs. Al Baqarah $\{2\}$ : 144\}. Ayat ini turun setelah Nabi SAW melakukan salat. Kemudian salah 
seorang dari satu kaum pergi melewati jama'ah kaum Anshar yang sedang salat, lalu dia memberitabukan kepada mereka peristiwa yang dialami Nabi. Maka mereka memalingkan wajah mereka ke arah Ka'bah." \{Shahih Muslim 2/65\} (Asqalani, 2003: 102).

Bagi orang yang berada di kota Makkah dan sekitarnya perintah menghadap kiblat ini tidak menjadi persoalan. Akan tetapi bagi mereka yang berada di luar bahkan jauh dari kota Makkah hal ini dapat menjadi masalah. Oleh sebab itu diperlukan usaha penetapan terkait arah kiblat, karena pada hakikatnya meskipun berada jauh dari kota Makkah hukumnya wajib menghadap ke arahnya secara tepat.

Masalah kiblat tiada lain adalah masalah arah, yaitu arah Ka'bah di Makkah. Kata kiblat berasal dari bahasa arab, yaitu قبلة yang berarti menghadap (Munawir, 1997: 1087). Kata kiblat dapat diartikan sebagai Ka’bah di Masjidil Haram Kota Makkah. Sebagian Ulama mendefinisikan kiblat sebagai bangunan Ka'bah atau arah yang dituju kaum muslimin dalam melaksanakan salat (Syarif, 2012). Sedangkan beberapa ahli ilmu falak mendefinisikan kiblat sebagai arah (jihah atau syatrah), yaitu arah ke Ka'bah di Masjidil Haram.

Arah Ka'bah ditentukan dari setiap titik atau tempat di permukaan bumi dengan melakukan perhitungan dan pengukuran. Arah yang dituju tersebut merupakan jarak terdekat sepanjang lingkaran besar yang melewati kota Makkah dengan tempat kota yang bersangkutan (Jihad, 2012).

Para ulama sepakat bahwa kiblat dalam melaksanakan salat hukumnya adalah wajib, karena menghadap kiblat merupakan salah satu syarat sah salat. Sebagaimana dijelaskan dalam Q.S. al-Baqarah (2): 144.

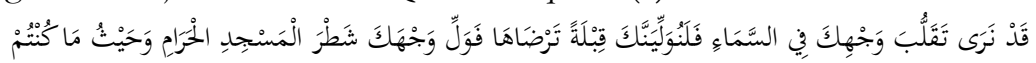

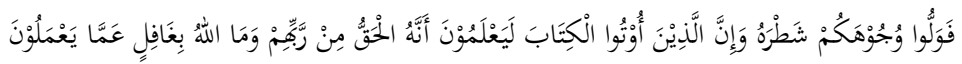

"Sungguh kami (sering) melihat mukamu menengadah ke langit. Maka sungguh kami akan memalingkan kamu ke kiblat yang kamu sukai. palingkanlah mukamu ke arah Masjid al-Haram. dan di mana saja kamu berada, palingkanlah mukamu ke arabnya. dan Sesunggubnya orang-orang (Yabudi dan Nasrani) yang diberi Al Kitab (Taurat dan Injil) memang mengetabui, bahwa berpaling ke Masjidil Haram itu adalab benar dari Tuhannya; dan Allab sekali-kali tidak lengah dari apa yang mereka kerjakan." (Cordoba, 2016: 22).

Kemudian diperkuat dengan hadis Nabi saw. yang diriwayatkan oleh Imam Bukhari (2004: 110): 


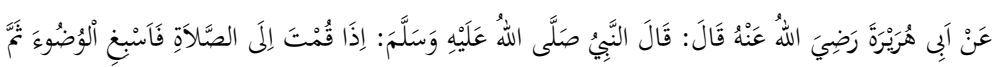

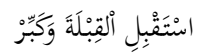

"Abu Hurairah berkata, Nabi saw bersabda, Bila bendak salat maka sempurnakanlah wudhu, lalu menghadaplah ke kiblat dan bertakbirlab'."

Pada zaman sekarang penentuan kiblat telah memiliki beberapa metode baik melalui perhitungan dengan menggunakan rumus spherical trigonometri, teori geodesi, maupun navigasi. Pada penelitian ini, peneliti menggunakan perhintungan dengan menggunakan spherical trigonometri dengan asumsi bahwa Bumi berbentuk bola sehingga yang perlu diukur adalah permukaannya.

Jika titik Ka'bah dan titik tempat salat dihubungkan dengan titik Utara, maka akan terbentukalah sebuah segitiga dengan tiga titik sudutnya. Segitiga yang terbentuk itu adalah segitiga bola (spherical trigonometri) karena ketiga sisinya merupakan busur dari lingkaran besar. Karena segitiga ini terkait dengan arah kiblat, maka para ahli ilmu falak terkadang menyebut dengan segitiga bola arah kiblat (Tim Majelis Tarjih dan Tajdid PP Muhammadiyah, 2009: 29). Dari segitiga bola inilah tersusun rumus untuk menghitung arah kiblat.

Sebagaimana terlihat pada gambar 1, arah kiblat adalah arah busur BA. Untuk mengetahui arah busur $\mathrm{BA}$, terlebih dahulu harus mengetahui sudut ABC. Sudut ABC adalah sudut arah kiblat dengan 3 (tiga) buah titik ABC. Titik $\mathrm{ABC}$ itu adalah:

a) Titik A adalah posisi Ka’bah di Mekah;

b) Titik $\mathrm{B}$ adalah posisi tempat yang akan ditentukan arah kiblatnya;

c) Titik $\mathrm{C}$ adalah posisi Kutub Utara.

Titik A dan titik $\mathrm{C}$ adalah 2 (dua) titik yang tetap, karena titik A tepat di Ka'bah dan titik C tepat di kutub Utara. Sedangkan titik B senantiasa berubah tergantung lokasi tempat mana yang akan dihitung arah kiblatnya. Bila ketiga titik tersebut dihubungkan dengan garis lengkung permukaan bumi, maka terbentuknya segitiga bola $\mathrm{ABC}$, seperti pada gambar 1 .

Ketiga sisi segitiga $A B C$ pada gambar 1 diberi nama dengan huruf kecil, masing-masing sisi a, sisi b, dan sisi c. Dari gambar di atas, bahwa yang dimaksud dengan perhitungan Arah Kiblat adalah suatu perhitungan untuk mengetahui berapa besar nilai sudut $\mathrm{K}$ di titik B. 


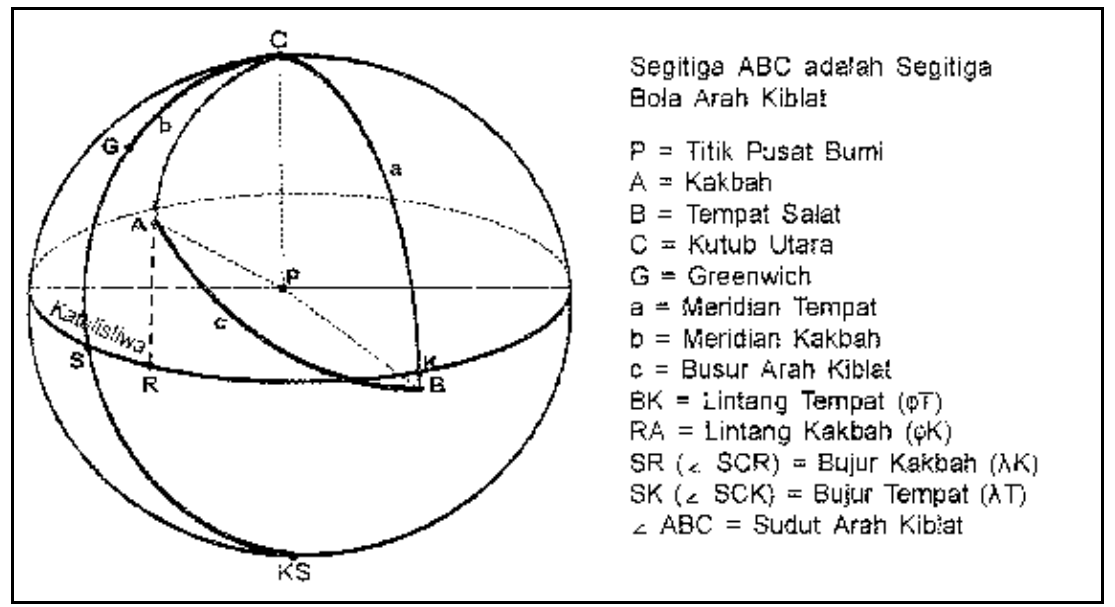

Gb. 1. Segitiga Bola Arah Kiblat

Untuk menghitung besaran sudut $\mathrm{ABC}$ dapat digunakan rumus:

Cotan $\mathrm{B}=\frac{\operatorname{Cotan} \mathrm{b} x \operatorname{Sin} \mathrm{a}}{\mathrm{a} \quad}-\operatorname{Cos} \mathrm{a} \times \operatorname{Cotan} \mathrm{C}$
$\mathrm{b} \quad=90^{\circ}-\varphi \mathrm{T} \quad \operatorname{Sin} \mathrm{C}$
$\angle \mathrm{C}=\lambda \mathrm{T}-\lambda \mathrm{K}$

Keterangan:

$\begin{array}{ll}\varphi \mathrm{T}=\text { lintang tempat } & \lambda \mathrm{T}=\text { bujur tempat } \\ \varphi \mathrm{K}=\text { lintang Ka'bah } & \lambda \mathrm{K}=\text { bujur Ka'bah }\end{array}$

Apabila besaran sudut ABC sudah diketahui, maka arah busur BA pun dapat dilihat hasilnya, karena busur BC menunjuk arah utara selatan sejati (Tim Majelis Tarjih dan Tajdid PP Muhammadiyah, 2009: 30-31).

Untuk perhitungan arah kiblat, hanya diperlukan dua data:

(1) Koordinat Ka’bah $\varphi=21^{\circ} 25^{\prime} \mathrm{LU}$ dan $\lambda=39^{\circ} 50^{\prime} \mathrm{BT}$.

(2) Koordinat lokasi yang akan dihitung arah kiblatnya.

Adapun data lintang dan bujur tempat lokasi yang akan dihitung dapat diambil dari tabel geografis kota-kota di dunia, atau dengan menggunakan GPS dan software-software yang ada seperti google earth, stellarium, starynight, dan lainnya.

Namun ada hal yang perlu dicermati bahwa dari beberapa metode di atas terkadang masih terdapat kekeliruan pada saat penentuan yang mengakibatkan kiblat menjadi tidak akurat. Hal tersebut dapat diakibatkan oleh beberapa faktor, 
di antaranya penentuan kiblat masjid mengikuti bangunan masjid lainnya yang sudah ada, pola pikir masyarakat yang cenderung sulit menerima perubahan seperti asumsi bahwa kiblat menghadap ke Barat, kelalaian pada saat pembangunan masjid yang mengakibatkan posisi kiblat menjadi bergeser, dan alat bantu yang digunakan memiliki tingkat akurasi yang rendah sehingga menyebabkan kiblat menjadi tidak akurat.

Oleh sebab itu, ketelitian dan kehati-hatian harus diusahakan dalam menentukan kiblat. Sehingga dalam melaksanakan ibadah, hati menjadi yakin. Apalagi saat ini sudah banyak peralatan yang mendukung untuk dapat mendapatkan tingkat keakuratan yang tinggi, seperti dengan menggunakan teodolite, mizwala, teleskop, kompas sunto, dan alat-alat lainnya, tentunya dengan cara penggunaan dan nilai keakuratan yang berbeda antara satu dengan yang lainnya.

\section{PENDAMPINGAN PENGUKURAN ARAH KIBLAT MASJID DI DESA RANCABANGO GARUT}

Desa Wangunsari adalah salah satu desa yang ada di kecamatan Lembang Kabupaten Bandung Barat, terdiri dari beberapa kampung di dalamnya, yaitu Kampung Areng, Kampung Cijengkol, Kampung Ciaruteun Wetan, Kampung Wangunsari, dan Kampung Cicalung. Sebagian besar penduduknya bermata pencaharian sebagai petani sayur, petani sapi, petani kelinci, dan buruh.

Di desa ini, terdapat 18 masjid yang biasa digunakan untuk salat berjamaah yang tersebar di beberapa kampung. Berdasarkan studi pendahuluan yang telah dilakukan peneliti, beberapa masjid yang telah diukur arah shaf salatnya ternyata menyimpang arah kiblatnya beberapa derajat dari yang seharusnya. Apabila dilakukan perhitungan terhadap arah kiblat dari Lembang, maka jarum mata angin seharusnya menunjukkan angka $295^{\circ}$ (derajat), namun tidak demikian. Beberapa masjid yang saat ini telah diukur oleh peneliti arah kiblatnya, sebagian besar tidak menghadap ke arah tempat Ka'bah berada, di antaranya Masjid alFurqon $298^{\circ}\left(+3^{\circ}\right)$, Masjid Nurul Huda $316^{\circ}\left(+21^{\circ}\right)$, Masjid at-Tawakkal $302^{\circ}$ $\left(+7^{\circ}\right)$, Masjid Nurul Ikhlas $287^{\circ}\left(-8^{\circ}\right)$, Masjid al-Fukah $290^{\circ}\left(-5^{\circ}\right)$, dan Masjid Sabilussalam $282^{\circ}\left(-13^{\circ}\right)$.

Berdasarkan hasil survei dan wawancara dengan Setyanto (2016) dari Observatorium Imah Noong, pengetahuan masyarakat yang tinggal di sekitar masjid tentang pentingnya arah kiblat masih dikatakan minim. Oleh karenanya, dengan melibatkan para DKM yang ada di masjid-masjid tersebut, program pengabdian tentang pelurusan shaf salat di masjid dapat terealisasikan. 
Upaya pendampingan pengukuran arah kiblat di Desa Ranca bango melalui tiga tahap. Pertama, tahap pengenalan. Pada tahap ini, penulis bersama tim melakukan pendekatan secara berkesinambugnan terhadap para pemangku desa, seperti tokoh masyarakat, kyai, ustadz, dan perangkat desa. Pendekatan ini dilakukan secara intensif dalam kurun waktu dua bulan.

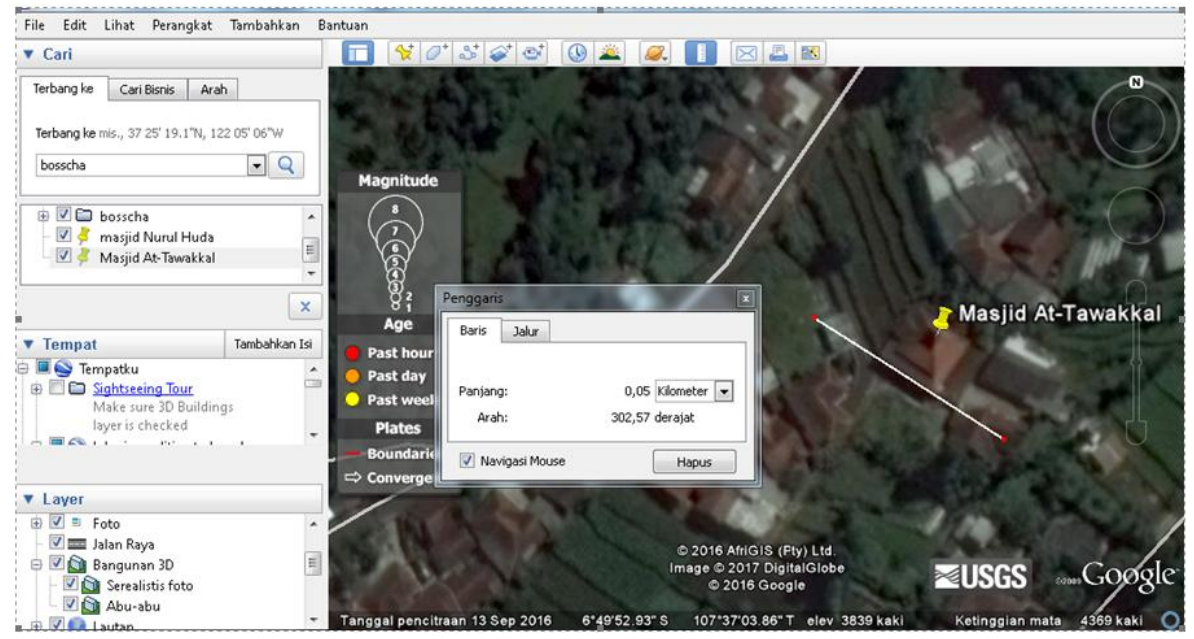

Gb. 2 Contoh Salah Satu Arah Bangunan Masjid At-Tawakkal Menggunakan Software Google Earth

Dalam kurun waktu tersebut, pandangan dan persepsi masyarakat setempat terkait arah kiblat masjid digali sedemikian rupa. Gambaran hasil citra google map yang menunjukkan arah kiblat di desa ini diberikan dengan seksama. Hasilnya diketahui masyarakat setempat terbuka dalam mensikapi perubahan dan pengukuran arah kiblat terhadap masjid yang ada. Keterbukaan ini dikarenakan pemangku dan masyarakat secara umum terbuka terhadap perkembangan teknologi. Juga pandangan bahwa penentuan arah kiblat merupakan wilayaha ijtihad yang boleh saja dilakukan perubahan.

Kedua, tahap persiapan. Pada tahap ini tim mengadakan pelatihan pengukuran penetuan arah kiblat. Beberapa elemen yang terlibat dari elemen diantaranya, pengurus takmir, pemuda atau remaja masjid, dan penggerak karang taruna. Elemen pemuda sengaja dilibatkan karena pada proses praktis pengukuran arah kiblat membutuhkan tenaga yang terampil untuk mengoperasikan beragam peralatan pengukruan arah kiblat. Pada proses kedua ini, ada enam pemuda yang benar-benar siap untuk ikut bersama-sama melakukan pengukuran arah kiblat. Ketiga, tahap pelaksanaan lapangan. Disini 
tim bersama dengan enam pemuda tadi melakukan pengukuran arah kiblat di beberapa masjid di Ranca Bango.

Pola pendampingan yang dilakukan pertama kali terhadap masyarakat setempat adalah dengan memberikan penyuluhan intensif. Pengetahuan secara umum tentang pentingnya untuk melakukan verifikasi terhadap arah kiblat masjid senantiasa disampaikan dan disosialisasikan secara berkelanjutan. Penulis mengajak diskusi para anggota DKM setempat, baik dengan cara mengumpulkannya secara langsung pada satu tempat, maupun mendatangi tempat tinggal secara personal. Sebagian besar memerlukan alat bantu pada saat sosialisasi dengan menggunakan software stellarium maupun google earth untuk memberikan simulasi dengan jelas dan rinci. Setelah dilakukan sosialisasi tahap awal, peneliti kemudian melakukan observasi dan verifikasi arah kiblat dengan menggunakan beberapa alat bantu seperti mizwala, google earth, kompas sunto, dan GPS untuk mendapatkan hasil azimuth bangunan berikut kemelencengan arah kiblat di bangunan masjid tersebut.

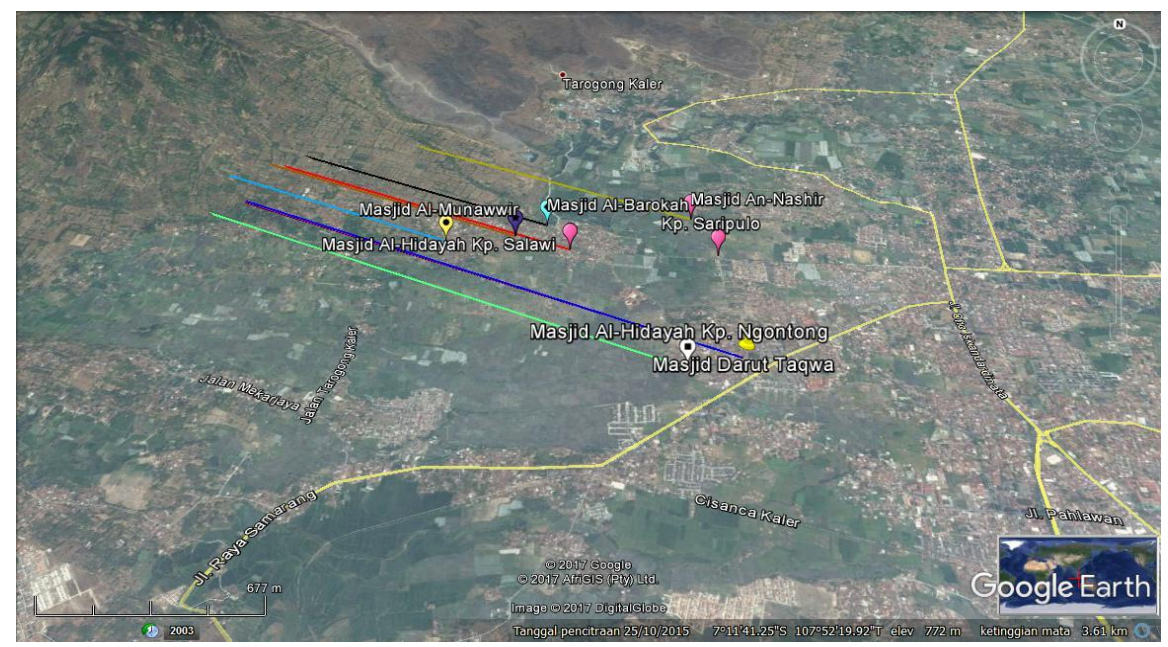

Gb. 3 Arah Kiblat Masjid-Masjid di Desa Rancabango Kecamatan Tarogong Kaler Kabupaten Garut

Analisis terhadap arah kiblat masjid-masjid di Desa Rancabango ini diarahkan pada harga sudut arah kiblat senyatanya dari tujuh masjid tersebut. Adapun datanya diperoleh melalui observasi pengukuran di lapangan dengan menggunakan Mizwala Qibla Finder, kompas Sunto, GPS, serta Stellarium. Data mengenai harga sudut arah kiblat yang senyatanya tersebut kemudian diverifikasi 
dengan harga sudut arah kiblat yang seharusnya yang diperoleh dari hasil perhitungan menggunakan rumus spherical trigonometri dan hasil pengamatan dengan bantuan software Google Earth, mizwala qibla finder, dan kompas Sunto.

Berdasarkan hasil pengamatan penulis dengan bantuan software Google Earth bahwa arah kiblat masjid-masjid di Desa Rancabango berada pada azimuth $295.18^{\circ}$ atau $295^{\circ} 10^{\prime} 48^{\prime \prime}$ atau 640 49' 12" dari Utara ke Barat.

Kota Makkah dan sekitarnya memiliki batas wilayah dengan batas-batas arah Barat $22 \mathrm{~km}$ dari Ka'bah, arah Selatan $14 \mathrm{~km}$, arah Timur $15 \mathrm{~km}$, dan arah Utara $10 \mathrm{~km}$. Di bawah ini gambar terkait batas wilayah dari Ka'bah ke titik Selatan dan Utara.

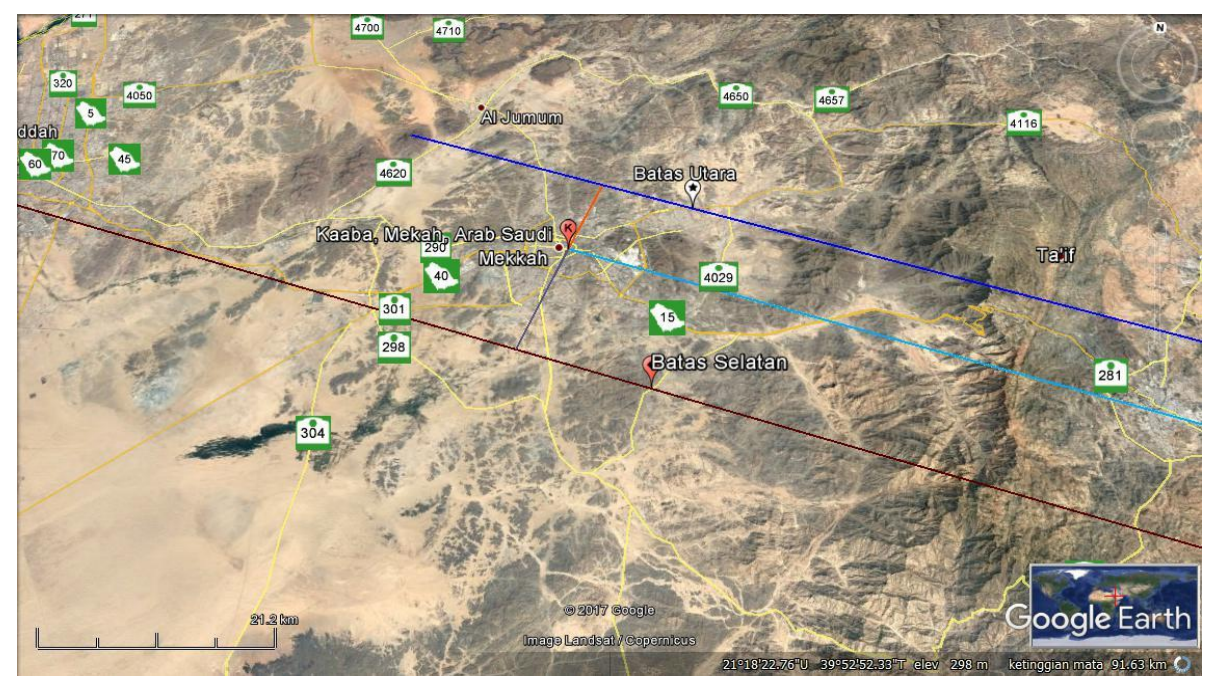

Gb. 4 Batas Selatan dan Utara Kota Makkah

Gambar 3 dan 4 menunjukkan arah dari masjid-masjid yang menjadi objek penelitian. Jika arah kiblat masjid-masjid tersebut berada pada azimuth $295.18^{\circ}$ atau $295^{\circ} 10^{\prime} 48^{\prime \prime}$ atau 6449'12", maka jika mengarah pada batas Selatan

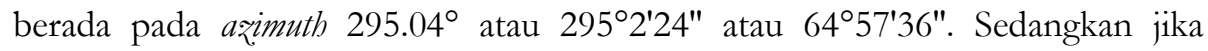
mengarah pada batas Utara azimuth $295.28^{\circ}$ atau $295^{\circ} 16^{\prime} 48^{\prime \prime}$ atau 64² $43^{\prime} 12^{\prime \prime}$. Selisih dari Ka'bah ke batas Selatan adalah $0^{\circ} 8^{\prime} 2^{\prime \prime}$, sedangkan untuk batas Utara adalah $0^{\circ} 6^{\prime} 0^{\prime \prime}$.

Di bawah ini merupakan proses perhitungan arah kiblat salah satu masjid di Desa Rancabango, Kecamatan Tarogong Kaler, Kabupaten Garut, yaitu :

Masjid Al-Muawwanah $\quad$ : Lintang $(\varphi)=-7^{\circ} 11^{\prime} 21.24^{\prime \prime}$ LS; 


$$
\operatorname{Bujur}(\lambda)=107^{\circ} 52^{\prime} 81^{\prime \prime} \text { BT. }
$$

\section{Penyelesaian:}

$$
\begin{aligned}
& a=90^{\circ}-\left(7^{\circ} 11^{\prime} 21.24^{\prime \prime} \mathrm{LS}\right)=\mathbf{9 7}^{\circ} \mathbf{1 1}^{\prime} \mathbf{2 1 . 2 4 ^ { \prime \prime }} \\
& \mathrm{b}=90^{\circ}-21^{\circ} 25^{\prime} 21.04^{\prime \prime} \mathrm{LU}=\mathbf{6 8}^{\circ} \mathbf{3} 4^{\prime} \mathbf{3 8}, \mathbf{9 6} 6^{\prime \prime} \\
& \mathrm{C}=107^{\circ} 52^{\prime} 81^{\prime \prime}-39^{\circ} 49^{\prime} 34.04^{\prime \prime}=\mathbf{6 8}^{\mathbf{o}} \mathbf{3}^{\prime} \mathbf{4 6 . 9 6 ^ { \prime \prime }}
\end{aligned}
$$

$\operatorname{Cotan} B=\frac{\operatorname{Cotan} 68^{\circ} 34^{\prime} 96 . \operatorname{Sin}_{97} 7^{\mathrm{x}} 11^{\circ} 21.24}{\operatorname{Sin} 68^{\circ} 3^{J} 46.96^{\mathrm{D}}}-\operatorname{Cos} 97^{\circ} 11^{\prime} 24 . \operatorname{Cotan} 68^{\circ} 3^{\circ} 46.96$

$\operatorname{Cotan} B=\frac{0,3923 \cdot 0,9921}{0,9275}-(-0,1251) .0,4027$

$\operatorname{Cotan} B=0,4699 \quad \Rightarrow \quad B=64,8311$

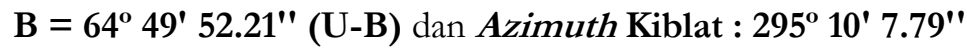

Jadi letak arah kiblat Masjid Al-Muawwanah berdasarkan pada perhitungan rumus spherical trigonometri adalah sebesar $64^{\circ} 49^{\prime} 52.21^{\prime \prime}$ dari Utara ke arah Barat dengan Azimuth Kiblat sebesar 295'10' 7.79". Tabel 1

\begin{tabular}{|c|c|c|c|c|c|c|}
\hline Masjid & Lintang & Bujur & $\begin{array}{c}\text { Arah } \\
\text { kiblat } \\
\text { (B-U) }\end{array}$ & $\begin{array}{c}\text { Azimuth } \\
\text { kiblat }\end{array}$ & $\begin{array}{l}\text { Lapang } \\
\text { an }\end{array}$ & Selisih \\
\hline $\begin{array}{l}\text { Masjid Al- } \\
\text { Muawwanah }\end{array}$ & $\begin{array}{l}7^{\circ} 11 ' 21 . \\
24^{\prime \prime} \mathrm{LS}\end{array}$ & $\begin{array}{c}107^{\circ} 52^{\prime} 8 \\
1^{\prime \prime} \mathrm{BT}\end{array}$ & $\begin{array}{c}64^{\circ} 49^{\prime} 5 \\
2.21^{\prime \prime}\end{array}$ & $\begin{array}{c}295^{\circ} 10^{\prime} 7.7 \\
9^{\prime \prime}\end{array}$ & $294^{\circ}$ & $1^{\circ}$ \\
\hline $\begin{array}{c}\text { Masjid Al- } \\
\text { Barokah }\end{array}$ & $\begin{array}{c}7^{\circ} 11^{\prime} 20 . \\
46^{\prime \prime} \mathrm{LS}\end{array}$ & $\begin{array}{c}107^{\circ} 52^{\prime} 1 \\
2.3^{\prime \prime} \mathrm{BT}\end{array}$ & $\begin{array}{c}64^{\circ} 49^{\prime} 3 \\
5.31^{\prime \prime}\end{array}$ & $\begin{array}{c}295^{\circ} 10^{\prime} 24 . \\
6^{\prime \prime}\end{array}$ & $298^{\circ}$ & $3^{\circ}$ \\
\hline $\begin{array}{c}\text { Masjid Al- } \\
\text { Hidayah } \\
\text { Kp. }\end{array}$ & $\begin{array}{c}7^{\circ} 11^{\prime} 49 . \\
26^{\prime \prime} \mathrm{LS}\end{array}$ & $\begin{array}{c}107^{\circ} 52^{\prime} 3 \\
3^{\prime \prime} \text { BT }\end{array}$ & $\begin{array}{c}64^{\circ} 49^{\prime} 2 \\
1.8^{\prime \prime}\end{array}$ & $\begin{array}{c}295^{\circ} 10^{\prime} 38 . \\
2^{\prime \prime}\end{array}$ & $295^{\circ}$ & $0^{\circ}$ \\
\hline Ngontong & & & & & & \\
\hline $\begin{array}{l}\text { Masjid An- } \\
\text { Nashir }\end{array}$ & $\begin{array}{c}7^{\circ} 11^{\prime} 15 . \\
54^{\prime \prime} \text { LS }\end{array}$ & $\begin{array}{c}107^{\circ} 52^{\prime} 3 \\
5.2^{\prime \prime} \mathrm{BT}\end{array}$ & $\begin{array}{c}64^{\circ} 49^{\prime} 2 \\
7.71 "\end{array}$ & $\begin{array}{c}295^{\circ} 10^{\prime} 32 . \\
2^{\prime \prime}\end{array}$ & $293^{\circ}$ & $2^{\circ}$ \\
\hline $\begin{array}{l}\text { Masjid Al- } \\
\text { Hidayah }\end{array}$ & $\begin{array}{c}7^{\circ} 11^{\prime} 25 . \\
68^{\prime \prime} \mathrm{LS}\end{array}$ & $\begin{array}{c}107^{\circ} 52^{\prime} 1 \\
6.3^{\prime \prime} \mathrm{BT}\end{array}$ & $\begin{array}{c}64^{\circ} 49^{\prime} 1 \\
8.42^{\prime \prime}\end{array}$ & $\begin{array}{c}295^{\circ} 10^{\prime} 41 \\
5^{\prime \prime}\end{array}$ & $302^{\circ}$ & $7^{\circ}$ \\
\hline
\end{tabular}
menggambarkan perbandingan harga sudut arah kiblat masjid-masjid di Desa Rancabango Kecamatan Tarogong Kaler Kabupaten Garut.

Tabel 1. Perbandingan Harga Sudut Arah Kiblat di Desa Ranca Bango 
Kp. Salawi

\begin{tabular}{ccccccc} 
Masjid Al- & $7^{\circ} 11^{\prime} 21$. & $107^{\circ} 51^{\prime} 5$ & $64^{\circ} 49^{\prime} 1$ & $295^{\circ} 10^{\prime} 44$. & $282^{\circ}$ & $13^{\circ}$ \\
Munawwir & $3^{\prime \prime} \mathrm{LS}$ & $8.2^{\prime \prime} \mathrm{BT}$ & $5.21^{\prime \prime}$ & $7^{\prime \prime}$ & & \\
Masjid & $7^{\circ} 11^{\prime} 48$. & $107^{\circ} 52^{\prime} 4$ & $64^{\circ} 49^{\prime} 2$ & $295^{\circ} 10^{\prime} 38$. & & \\
Darut & $1^{\prime \prime} \mathrm{LS}$ & $2^{\prime \prime} \mathrm{BT}$ & $1.8^{\prime \prime}$ & $2^{\prime \prime}$ & $297^{\circ}$ & $2^{\circ}$ \\
Taqwa & & & & & & \\
\hline
\end{tabular}

\section{KESIMPULAN}

Para ulama sepakat wajib hukumnya bagi umat Islam dalam salat, yang tidak memiliki udzur syar'i, untuk selalu menghadap kiblat ke Ka'bah. Adapun arah kiblat masjid-masjid yang menjadi objek penelitian menunjukkan bahwa beberapa masjid masih memiliki akurasi arah kiblat yang tidak akurat terhadap harga sudut yang telah ditentukan. Selisih derajat yang terlalu tinggi menyebabkan kiblat menjadi tidak tepat ke arah Ka'bah, sehingga menurut hemat penulis perlu dilakukan sosialisasi yang berkelanjutan untuk mengampanyekan arah kiblat yang akurat menghadap Ka'bah, dan hal ini dapat diterapkan langsung kepada masyarakat melalu pembelajaran yang praktis dan efektif.

Beberapa faktor yang menjadi penyebab kesalahan dalam penentuan arah kiblat masjid di Desa Rancabango dan Desa Wangunsari antara lain:

1. Kurangnya pengetahuan masyarakat sekitar tentang pentingnya menghadap kiblat saat salat;

2. Masih kuatnya kepercayaan masyarakat kepada tokoh setempat yang dianggap menguasai dan paham lokasi tersebut/arah kiblat di masjid tersebut, tanpa mengecek ulang arah kiblatnya dengan menggunakan instrumen falakiyah yang akurat;

3. Pada saat membangun masjid di awal, tidak diukur terlebih dahulu arah kiblatnya, ada beberapa masjid yang dibangun mengikuti posisi tanah yang ada atau mengikuti jalan;

4. Kesalahan dalam pengukuran arah kiblat, banyak yang masih menggunakan kompas tanpa dilakukan upaya kalibrasi terlebih dahulu;

5. Masih adanya anggapan bahwa menghadap kiblat cukup ke arah Barat saja, padahal posisi Ka'bah dari Indonesia berada di sebelah Barat agak ke Utara $\left( \pm 294^{\circ}\right)$, bergantung kepada posisi letak astronomis suatu daerah;

6. Belum adanya upaya untuk memverifikasi bangunan masjid yang berada di daerah pedalaman oleh pihak-pihak terkait. Hal ini dapat disebabkan belum terjangkaunya daerah tersebut dari wilayah perkotaan. 
Faktor terbesar yang menyebabkan terjadinya kesalahan dalam penentuan arah kiblat adalah sifat masyarakat yang cenderung konservatif. Hal tersebut dikarenakan minimnya pengetahuan masyarakat akan suatu disiplin ilmu dan agama. Akan tetapi, persoalan tersebut dapat diminimalisir dengan dibuatnya sebuah wadah pembelajaran dalam bingkai Madrasah Falakiyah/kegiatan penyuluhan-penyuluhan lainnya.

Dukungan dan kerjasama yang baik dengan pemerintah setempat sangat diperlukan oleh masyarakat sekitar yang menjadi objek penelitian. Korelasi yang terjalin antara peneliti, pemerintah setempat, dan masyarakat pedalaman akan memberikan dampak yang signifikan. Bagi peneliti, keberhasilan penelitian dapat memotivasi diri untuk senantiasa berkontribusi dalam pengembangan ilmu pengetahuan sekaligus mengamalkannya dalam kehidupan sehari-hari. Bagi pemerintah setempat, keberhasilan suatu penelitian yang diadakan dapat dijadikan tolok ukur berhasil atau tidaknya suatu pembangunan dalam bidang pendidikan khususnya. Adapun bagi masyarakat, keberhasilan penelitian akan memberikan ketenangan dalam beribadah, khususnya salat.

\section{DAFTAR PUSTAKA}

Awaluddin, M., Yuwono, B., Hani'ah, \& Wicaksono. (2016). Kajian Penentuan Arah Kiblat secara Geodetis. Jurnal Teknik, Vol. 37 (2). 84-88.

Asqalani, I.H. (2003). Fatbul Baari syarah: Shabih Bukhari, Penerjemah: Amiruddin. Jakarta: Pustaka Azzam.

Bukhory, A.A.M. (2004). Shahih Bukhari. Jilid I. Kairo: Dar al-Hadis.

Cordoba. (2016). Al-Qur'an Cordoba Terjemah Tematik dan Tajwid Berwarna (AlQur'an Tafsir bil Hadis). Bandung: Cordoba.

Darajat, M.H., Fadlil, A., \& Sunardi. (2016). Sistem Informasi Arah Kiblat dan Jadwal Waktu Shalat berbasis Android. Jurnal Teknologi, Vol. 9 (2). 148-155.

Hamdani, F.F.R.S. (2016). Penerapan Model Contextual Teaching and Learning (CTL) dalam Pembelajaran Ilmu Falak. Jurnal Al-Murabbi, Vol. 3 (1). 55-69.

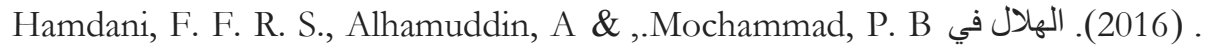
القرآن: تسمية الهلال وتطور ها عند علماء التفسير المتقدين و المعاصرين على وجه الموضوعي.TS AQAF AH.424-409, (2)12, 
Jayusman. (2014). Akurasi Metode Penentuan Arah Kiblat: Kajian Fiqh alIkhtilaf dan Sains. Jurnal ASAS, Vol. 6 (1). 72-86.

Jihad. S. (2012). Metode Perhitungan dan Pengukuran Arah Kiblat Masjid di Kota Mataram. Jurnal Penelitian Keislaman, Vol. 8 (1). 93-109.

Kamal, M. (2015). Teknik Penentuan Arah Kiblat Menggunakan Aplikasi Google Earth dan Kompas Kiblat RHI. Jurnal Madaniyah, Vol. 2 (9). 176197.

Mulyadi, A. (2013). Akurasi Arah Kiblat Masjid-masjid di Kabupaten Pamekasan. Jurnal Nuansa, Vol. 10 (1). 71-100.

Munawir, A.W. (1997). al-Munawir Kamus Arab-Indonesia. Surabaya: Pustaka Progressif.

Naik. Z. (2016). Answers to Non Muslim's Common Questions about Islam. Terjemahan Noor Cholis. Solo: Aqwam.

Setyanto, H., \& Hamdani, F. F. R. S. (2015). Kriteria 29: Cara pandang baru dalam penyusunan kalender hijriyah. Al-Abkam, 25(2), 205-220.

Shihab, M.Q. (2002). Tafsir Al-Misbah: Pesan, Kesan, dan Keserasian al-Qur'an, Jakarta: Lentera Hati.

Syarif, M.R. (2012). Problematika Arah Kiblat dan Aplikasi Perhitungannya. Hunafa: Jurnal Studia Islamika, Vol. 9 (2). 245-269.

Tim Majelis Tarjih dan Tajdid PP Muhammadiyah, (2009). Pedoman Hisab Muhammadiyah, Majelis Tarjih dan Tajdid PP Muhammadiyah: Yogyakarta 
